PREPARED FOR THE U.S. DEPARTMENT OF ENERGY, UNDER CONTRACT DE-AC02-76CH03073

PPPL-3565

PPPL-3565

UC-70

Investigation of Ion Absorption of the High Harmonic Fast Wave in NSTX using HPRT

A. Rosenberg, J.E. Menard, and B.P. LeBlanc

May 2001

M

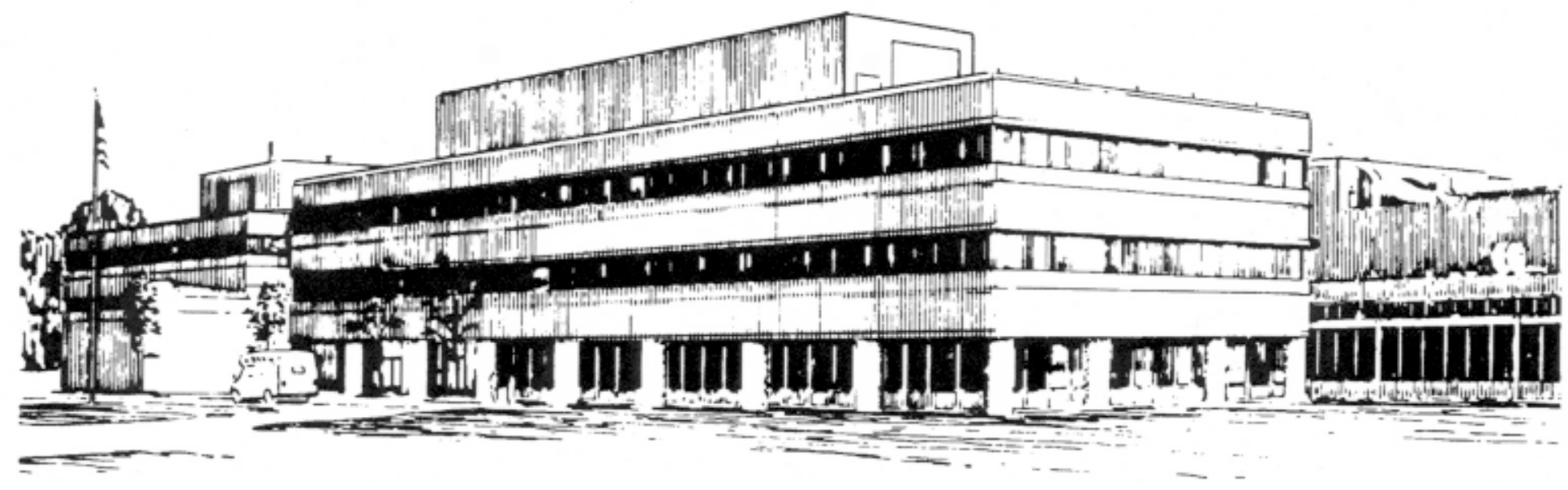

PRINCETON PLASMA PHYSICS LABORATORY PRINCETON UNIVERSITY, PRINCETON, NEW JERSEY 


\section{PPPL Reports Disclaimer}

This report was prepared as an account of work sponsored by an agency of the United States Government. Neither the United States Government nor any agency thereof, nor any of their employees, makes any warranty, express or implied, or assumes any legal liability or responsibility for the accuracy, completeness, or usefulness of any information, apparatus, product, or process disclosed, or represents that its use would not infringe privately owned rights. Reference herein to any specific commercial product, process, or service by trade name, trademark, manufacturer, or otherwise, does not necessarily constitute or imply its endorsement, recommendation, or favoring by the United States Government or any agency thereof. The views and opinions of authors expressed herein do not necessarily state or reflect those of the United States Government or any agency thereof.

\section{Availability}

This report is posted on the U.S. Department of Energy's Princeton Plasma Physics Laboratory Publications and Reports web site in Calendar Year 2001. The home page for PPPL Reports and Publications is: http://www.pppl.gov/pub_report/

DOE and DOE Contractors can obtain copies of this report from:

U.S. Department of Energy

Office of Scientific and Technical Information

DOE Technical Information Services (DTIS)

P.O. Box 62

Oak Ridge, TN 37831

Telephone: (865) 576-8401

Fax: (865) 576-5728

Email: reports@adonis.osti.gov

This report is available to the general public from:

National Technical Information Service

U.S. Department of Commerce

5285 Port Royal Road

Springfield, VA 22161

Telephone: 1-800-553-6847 or

(703) 605-6000

Fax: (703) 321-8547

Internet: http://www.ntis.gov/ordering.htm 


\title{
Investigation of Ion Absorption of the High Harmonic Fast Wave in NSTX using HPRT
}

\author{
A. Rosenberg, J.E. Menard, B.P. LeBlanc \\ Princeton Plasma Physics Lab, Princeton NJ, 08543
}

\begin{abstract}
Understanding high harmonic fast wave (HHFW) power absorption by ions in a spherical torus (ST) is of critical importance to assessing the wave's viability as a means of heating and especially driving current. In this work, HPRT is used to calculate absorption for He and D, with and without minority $\mathrm{H}$ in NSTX plasmas using experimental EFIT equilibria and kinetic profiles. HPRT is a 2D ray-tracing code which uses the full hot plasma dielectric to compute the perpendicular wave number along the hot electron/cold ion plasma ray path. Ion and electron absorption dependence on antenna phasing, ion temperature, $\beta_{t}$, and minority temperature and concentration is analyzed. These results form the basis for comparisons with other codes, such as CURRAY, METS, TORIC, and AORSA.
\end{abstract}

\section{INTRODUCTION}

The National Spherical Torus Experiment (NSTX) has an extensive RF system which launches high harmonic fast waves at $30 \mathrm{MHz}$ into the target plasma via a twelve-strap antenna array. Understanding the species breakdown of power absorption is of critical importance to assessing the wave's viability as a means of heating and especially driving current. HPRT is a 2-D ray-tracing code which uses the full hot plasma dielectric to compute the perpendicular wave number, and with this, the power absorption by species along the hot electron/cold ion plasma ray path [1]. In this work, HPRT is used to calculate absorption for He and D plasmas, with and without minority $\mathrm{H}$ in a model equilibrium and in NSTX plasmas using experimental EFIT equilibria and kinetic profiles. Ion and electron absorption dependence on antenna phasing, ion temperature, $\beta_{t}$, and minority temperature and concentration is examined.

\section{MODELLING RESULTS}

\section{A. Model High- $\beta$ Equilibria}

The model equilibrium electron temperature and density profiles are shown in Figures $1 \mathrm{a} \& \mathrm{~b}$. They are quite broad and optimized for MHD stability. Ion and electron profiles in the following studies were made by scaling these profiles while keeping the magnetic field strength fixed. $\mathrm{n}_{\phi}$ of 12 was often chosen because this is the nominal current drive phasing for NSTX, where $n_{\phi}$ is the number of wavelengths that fit toroidally around the plasma, set by the antenna array. In a deuterium plasma, deuterium power absorption can compete with electron absorption, as demonstrated in 

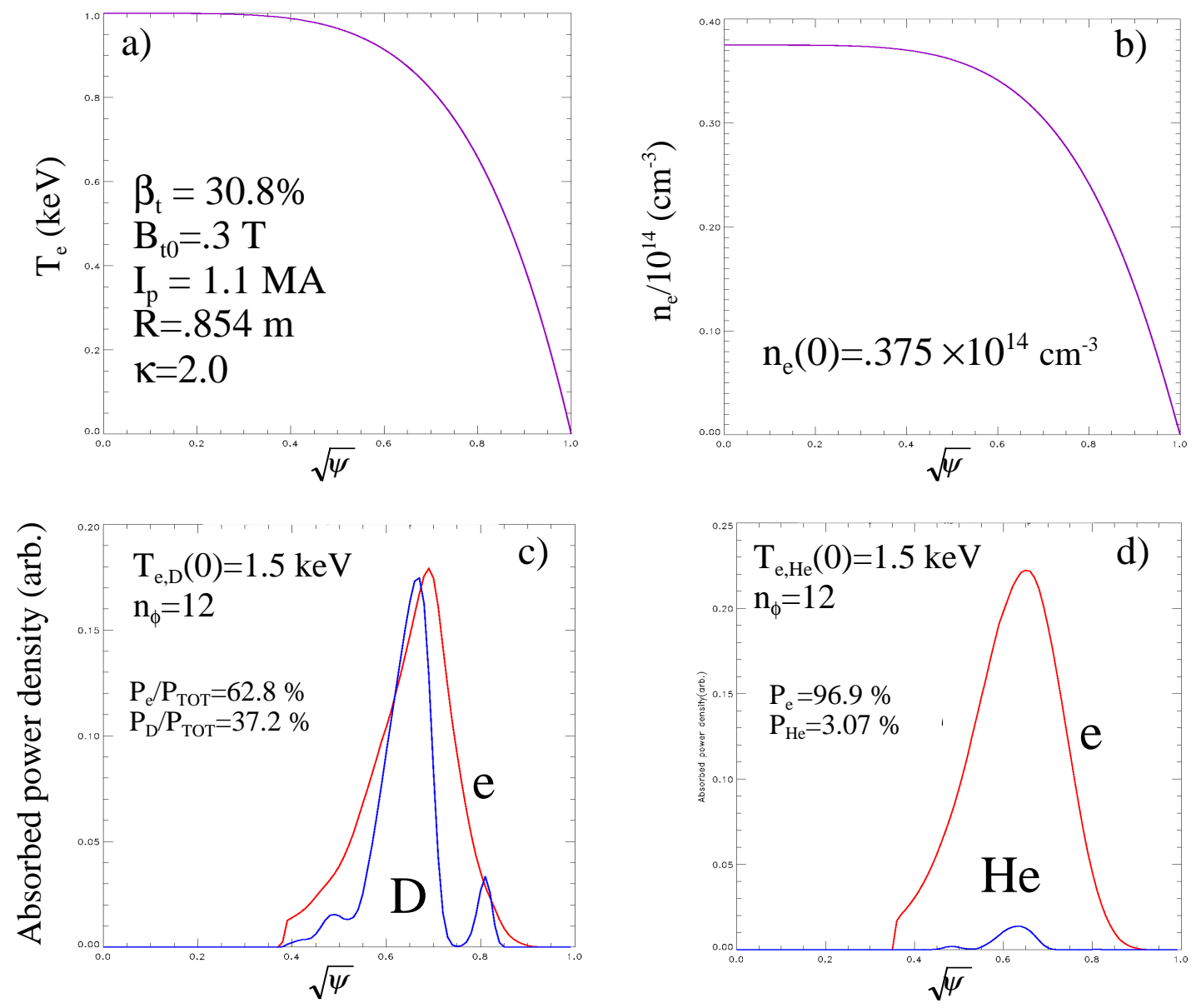

Figure 1: a) model equilibrium electron temperature profile, b) model density profile, c) power absorption in deuterium plasma, d) in helium plasma

Figure 1c. On the other hand, in a helium plasma, helium absorption is fairly insignificant. (See Fig. 1d) This is due to helium having a lower $k_{\perp} \rho_{i}$ and $\beta_{i}$ for fixed ion temperature and electron density. In either case, ion absorption increases with ion temperature and decreases with $n_{\phi}[1]$. (See Figs. 2c,d).

Minority hydrogen absorption was also analyzed using these profiles. Even at moderate plasma temperatures (setting $\mathrm{T}_{\mathrm{i}}=.75 \mathrm{~T}_{\mathrm{e}}$ ) and concentration of hydrogen, hydrogen power absorption can clearly dominate the ion absorption (Fig. 2a), and at higher temperatures, compete with electron absorption (Fig. 2b). Comparing Figs. 2a and $2 \mathrm{~b}$, it is also evident that electron absorption profiles move outward and become narrower with higher plasma temperatures. Figs. $2 \mathrm{c}$ and $2 \mathrm{~d}$ show the relative ion absorption vs. plasma temperature, $\mathrm{n}_{\phi}$, and $\% \mathrm{H}$. Hydrogen and deuterium both follow trends of increased absorption with increased plasma temperatures and decreased $n_{\phi}$. The relative hydrogen absorption vs. deuterium appears to increase dramatically with $\% \mathrm{H}$, and fractional power absorbed for $\mathrm{H}$ saturates at lower temperatures than $\mathrm{D}$. 

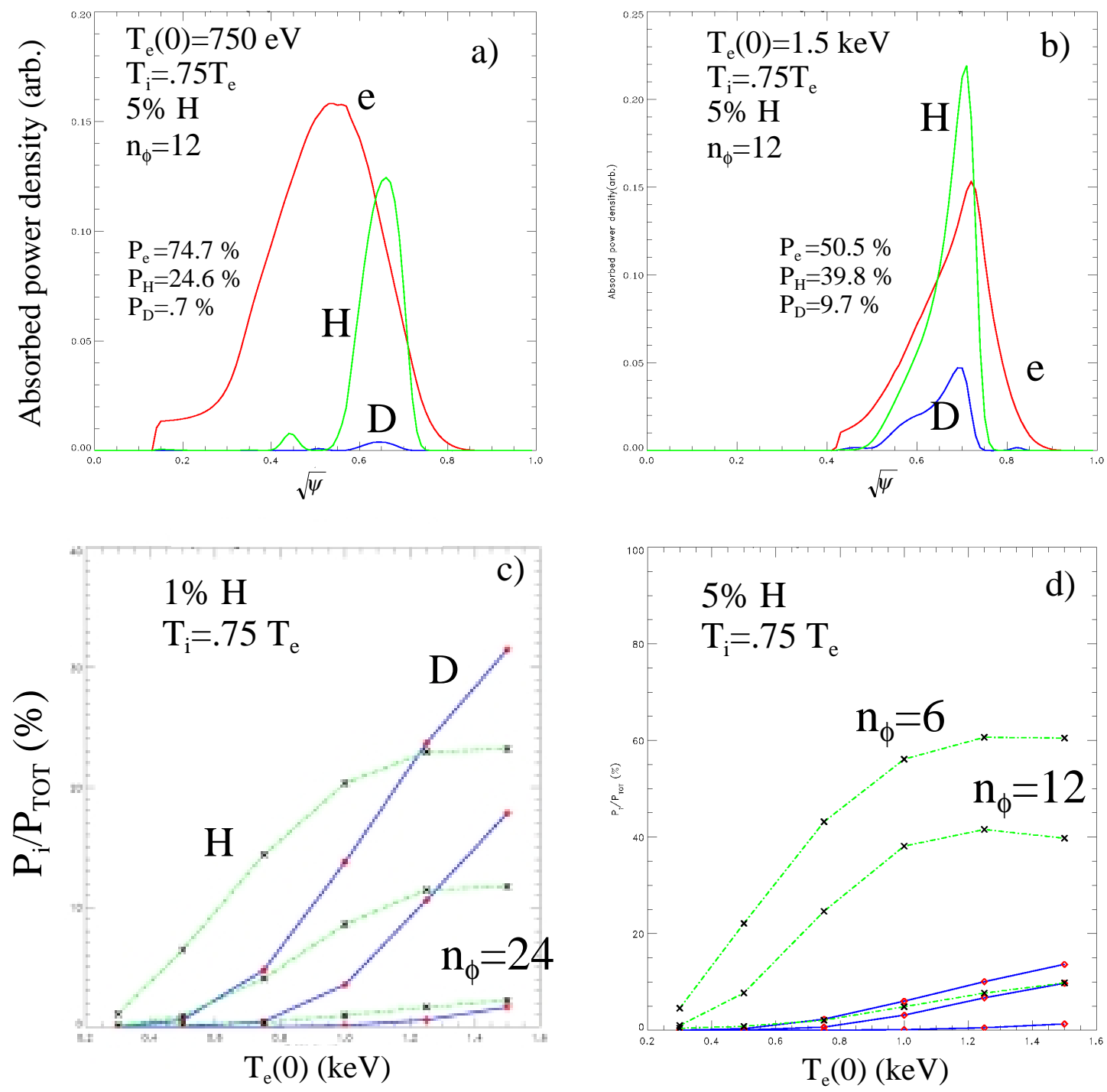

Figure 2: $\mathrm{T}_{\mathrm{i}}=.75 \mathrm{~T}_{\mathrm{e}}$, a) lower temperature ion absorption with $5 \% \mathrm{H}, \mathrm{b}$ ) higher temperature absorption, c) absorption vs. $\mathrm{T}_{\mathrm{e}}(0), \mathrm{n}_{\phi}$ with $\left.1 \% \mathrm{H} \mathrm{d}\right) 5 \% \mathrm{H}$

\section{B. Experimental NSTX Equilibria}

Measured NSTX equilibria have also been examined, particularly shot 104476. Electron temperature and density profiles for this shot are shown in Figures $3 a \& 3 b$. Notable differences between this and the model equilibrium include a much lower $\beta_{t}$ of $6 \%$ and more peaked profiles than the model. It should also be noted that in order to prevent the wave from leaving the plasma, the density profile was multiplied by a tanh function, bringing the edge density to zero. Comparing Fig. $3 c$ to $2 b$, it is clear that even with temperature and $\% \mathrm{H}$ scaled similarly, the measured data has far less hydrogenic absorption than the model. The sharp peaks are a 2-D effect resulting from the ray path being temporarily tangent to a flux surface. Fig. $3 \mathrm{~d}$ shows absorption with actual, unscaled data in order to simulate as accurately as possible what happened 
during this RF shot. From this, it is evident that ion absorption cannot account for the significantly lower electron temperatures in deuterium vs. helium plasmas observed thus far [2]. Future work will incorporate a distribution of initial antenna phasings into HPRT, analyze more shots, and study the effects of beam-heated ions, all of which will be a part of the first author's thesis.
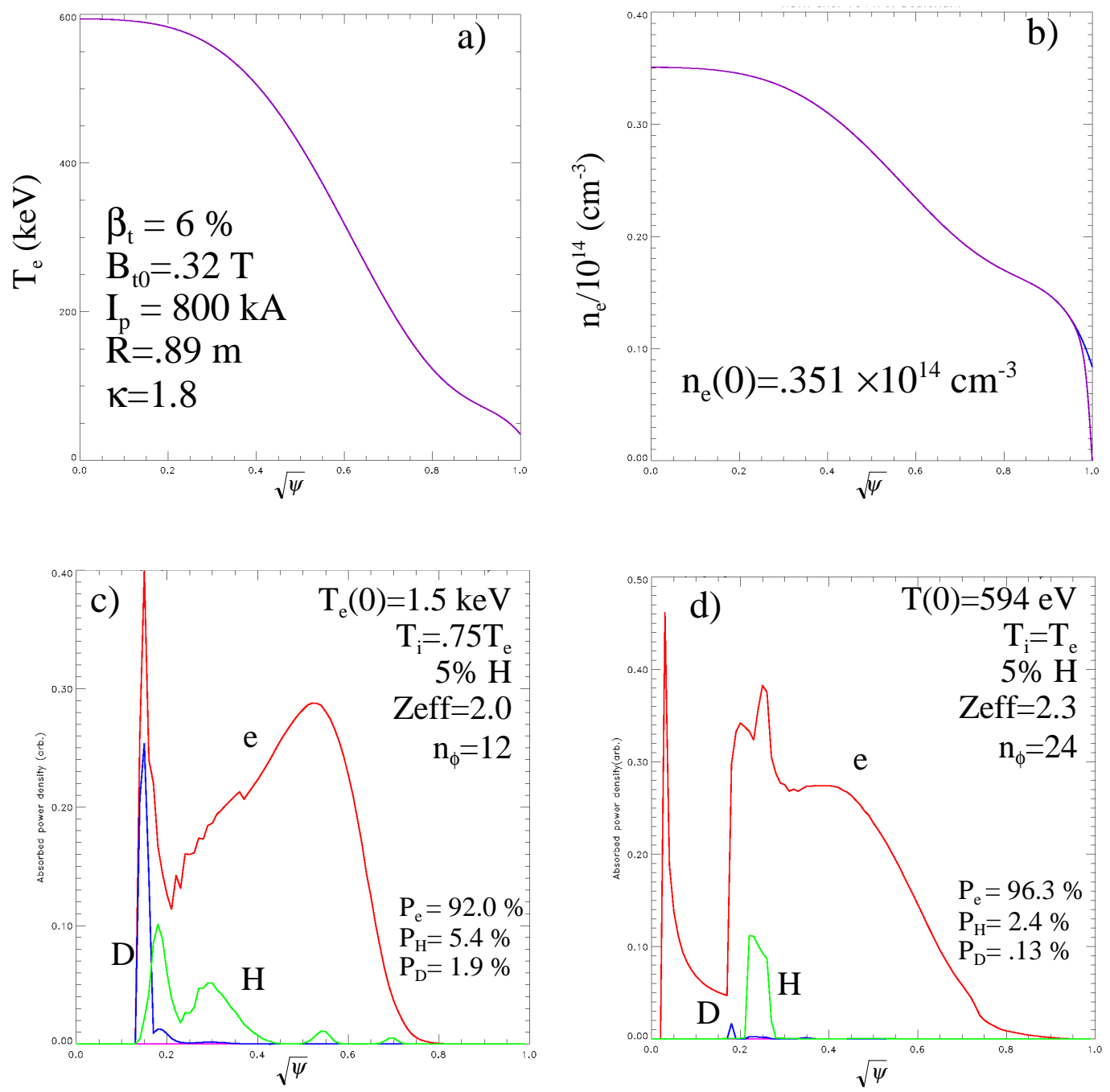

Figure 3: a) NSTX shot 104476 temperature profile b) 104476 density profile, with edge modification c) absorption in measured profile, $\mathrm{T}_{\mathrm{e}}(0)$ set to $1.5 \mathrm{keV} \mathrm{d}$ ) absorption with measured parameters and experimental $n_{\phi}=24$

\section{ACKNOWLEDGMENTS}

Work supported by DOE contract DE-AC02-76CH03073.

\section{REFERENCES}

1. J. Menard, R. Majeski, R. Kaita, M. Ono, T. Munsat, Phys. Plasmas 6 (1999) 2002.

2. B.P. LeBlanc et al., this conference. 


\section{External Distribution}

Plasma Research Laboratory, Australian National University, Australia

Professor I.R. J ones, Flinders University, Australia

Professor J oão Canalle, Instituto de Fisica DEQ/IF - UERJ , Brazil

Mr. Gerson O. Ludwig, Instituto Nacional de Pesquisas, Brazil

Dr. P.H. Sakanaka, Instituto Fisica, Brazil

The Librarian, Culham Laboratory, England

Library, R61, Rutherford Appleton Laboratory, England

Mrs. S.A. Hutchinson, JET Library, England

Professor M.N. Bussac, Ecole Polytechnique, France

Librarian, Max-Planck-Institut für Plasmaphysik, Germany

J olan Moldvai, Reports Library, MTA KFKI-ATKI, Hungary

Dr. P. Kaw, Institute for Plasma Research, India

Ms. P.J . Pathak, Librarian, Insitute for Plasma Research, India

Ms. Clelia De Palo, Associazione EURATOM-ENEA, I taly

Dr. G. Grosso, Instituto di Fisica del Plasma, Italy

Librarian, Naka Fusion Research Establishment, J AERI, J apan

Library, Plasma Physics Laboratory, Kyoto University, J apan

Research Information Center, National Institute for Fusion Science, J apan

Dr. O. Mitarai, Kyushu Tokai University, J apan

Library, Academia Sinica, Institute of Plasma Physics, People's Republic of China

Shih-Tung Tsai, Institute of Physics, Chinese Academy of Sciences, People's Republic of China

Dr. S. Mirnov, TRINITI, Troitsk, Russian Federation, Russia

Dr. V.S. Strelkov, Kurchatov Institute, Russian Federation, Russia

Professor Peter Lukac, Katedra Fyziky Plazmy MFF UK, Mlynska dolina F-2, Komenskeho Univerzita, SK-842 15 Bratislava, Slovakia

Dr. G.S. Lee, Korea Basic Science Institute, South Korea

Mr. Dennis Bruggink, Fusion Library, University of Wisconsin, USA

Institute for Plasma Research, University of Maryland, USA

Librarian, Fusion Energy Division, Oak Ridge National Laboratory, USA

Librarian, Institute of Fusion Studies, University of Texas, USA

Librarian, Magnetic Fusion Program, Lawrence Livermore National Laboratory, USA

Library, General Atomics, USA

Plasma Physics Group, Fusion Energy Research Program, University of California at San Diego, USA

Plasma Physics Library, Columbia University, USA

Alkesh Punjabi, Center for Fusion Research and Training, Hampton University, USA

Dr. W.M. Stacey, Fusion Research Center, Georgia Institute of Technology, USA

Dr. J ohn Willis, U.S. Department of Energy, Office of Fusion Energy Sciences, USA

Mr. Paul H. Wright, Indianapolis, Indiana, USA 
The Princeton Plasma Physics Laboratory is operated by Princeton University under contract with the U.S. Department of Energy.

\author{
Information Services \\ Princeton Plasma Physics Laboratory \\ P.O. Box 451 \\ Princeton, NJ 08543
}

Phone: 609-243-2750

Fax: 609-243-2751

e-mail: pppl_info@pppl.gov

Internet Address: http://www.pppl.gov 